\title{
Transient perivascular inflammation of the carotid artery syndrome
}

\author{
Toshinori Nishizawa 자, ${ }^{1}$ Haruhiro Uematsu ${ }^{2}$
}

${ }^{1}$ Department of General Internal Medicine, St Luke's International Hospital, Chuo-ku, Japan ${ }^{2}$ Department of General Internal Medicine, Toyota Regional Medical Center, Toyota, Japan

\section{Correspondence to} Dr Toshinori Nishizawa; nishizawa.toshinori@gmail.com

Accepted 29 December 2021

\section{DESCRIPTION}

A 74-year-old man presented with a 2-day history of right-sided neck pain. He denies preceding episodes of infection or trauma. Physical examination revealed localised tenderness on the right carotid artery. No vascular murmur was detected. White cell count, $\mathrm{C}$ reactive protein and erythrocyte sedimentation rate were all within the normal range. Ultrasonography showed an eccentric hypoechoic lesion in the perivascular tissue at the level of bifurcation of the right carotid artery without the lumen narrowing or dissection (figure 1), findings were consistent with transient perivascular inflammation of the carotid artery (TIPIC). After taking acetaminophen, the neck pain subsided at a 2 -weak follow-up. The follow-up ultrasonography showed a striking improvement of the perivascular lesion, which confirmed the diagnosis (figure 2).

TIPIC is a newly recognised syndrome of acute cervical pain, consisting of transient perivascular inflammation at the level of the carotid bifurcation, which describes a distinct clinicoradiologic entity previously known as carotidynia or Fay syndrome. ${ }^{2}$ In 2017, Lecler, et al published a clinicoradiological description of TIPIC syndrome, addressing four major criteria: acute pain over the carotid artery (may or may not radiate to the head), eccentric perivascular inflammation on imaging, exclusion of other diagnoses by imaging and improvement either spontaneously or with anti-inflammatory drugs within 14 days. ${ }^{1}$ The mean age at diagnosis is

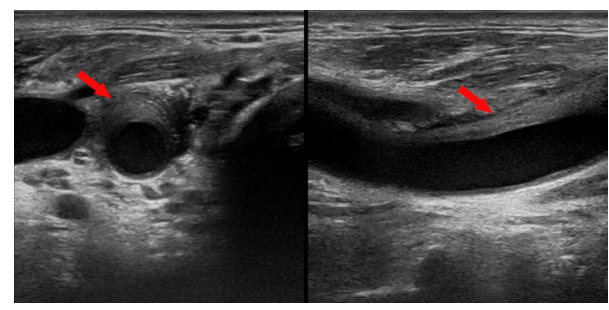

Figure 1 Ultrasonography showed an eccentric hypoechoic lesion (red arrow) in the perivascular tissue at the level of bifurcation of the right carotid artery.

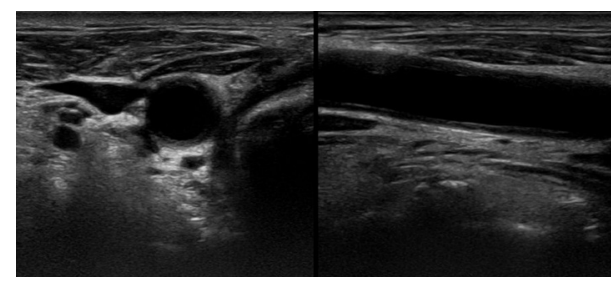

Figure 2 The follow-up ultrasonography showed striking decrease of the perivascular lesion.

\section{Patient's perspective}

I did not know what was causing it at first, but it got better spontaneously in about 2 weeks. I am very grateful for making the diagnosis. I feel relieved.

\section{Learning points}

- Transient perivascular inflammation of the carotid artery (TIPIC) is a newly recognised syndrome of acute cervical pain, consisting of transient perivascular inflammation at the level of the carotid bifurcation.

- Although TIPIC syndrome is rare, it is probably underestimated because of its relatively mild symptoms and rapid improvement.

- Ultrasonography has the advantage of investigating the exact point of tenderness as directed by the patient and is readily available for follow-up and comparison with the initial study.

37 years (15-78 years). Pain is unilateral in 90\% of cases. ${ }^{3}$ The cause of TIPIC is unknown. Although TIPIC syndrome is rare (estimated prevalence of $2.8 \%$ in patients presenting with acute neck pain), it is probably underestimated because of its relatively mild symptoms and rapid improvement. Furthermore, ultrasonography has the advantage of investigating the exact point of tenderness as directed by the patient and is readily available for follow-up and comparison with the initial study.

In summary, we report a typical clinical and radiological feature of TIPIC syndrome. Primary care physicians should remember this new recognised syndrome of acute cervical pain and perform ultrasonography.

Acknowledgements The authors wish to thank Yasuhiro Osugi, Toyota Regional Medical Center, Toyota, Aichi, Japan, for his kind support.

Contributors TN cared the patient and wrote the report. Both authors read and approved the final version of the report.

Funding The authors have not declared a specific grant for this research from any funding agency in the public, commercial or not-for-profit sectors.

Competing interests None declared.

Patient consent for publication Consent obtained directly from patient(s).

Provenance and peer review Not commissioned; externally peer reviewed. 
Images in...

Case reports provide a valuable learning resource for the scientific community and can indicate areas of interest for future research. They should not be used in isolation to guide treatment choices or public health policy.

\section{ORCID iD}

Toshinori Nishizawa http://orcid.org/0000-0003-2074-646X

\section{REFERENCES}

1 Lecler A, Obadia M, Savatovsky J, et al. TIPIC syndrome: beyond the myth of carotidynia, a new distinct unclassified entity. AJNR Am J Neuroradiol 2017;38:1391-8.

2 Biousse V, Bousser MG. The myth of carotidynia. Neurology 1994;44:993-5.

3 Abrahamy M, Werner M, Gottlieb P, et al. Ultrasound for the diagnosis of carotidynia. J Ultrasound Med 2017;36:2605-9.

Copyright 2021 BMJ Publishing Group. All rights reserved. For permission to reuse any of this content visit

https://www.bmi.com/company/products-services/rights-and-licensing/permissions/

BMJ Case Report Fellows may re-use this article for personal use and teaching without any further permission.

Become a Fellow of BMJ Case Reports today and you can:

- Submit as many cases as you like

- Enjoy fast sympathetic peer review and rapid publication of accepted articles

- Access all the published articles

Re-use any of the published material for personal use and teaching without further permission

\section{Customer Service}

If you have any further queries about your subscription, please contact our customer services team on +44 (0) 2071111105 or via email at support@bmj.com.

Visit casereports.bmj.com for more articles like this and to become a Fellow 